\title{
Comparison of social media platforms in terms of marketing performances of food companies
}

\author{
Seren Celimli and Hakan Adanacioglu* \\ Department of Agricultural Economics, Faculty of Agriculture, Ege University, Bornova, 35100 Izmir, Turkey
}

"Corresponding Author: Hakan Adanacioglu, Department of Agricultural Economics, Faculty of Agriculture, Ege University, Bornova, 35100 Izmir, Turkey. E-mail: hakan.adanacioglu@ege.edu.tr

Received: 12 March 2021; Accepted: 19 April 2021; Published: 14 May 2021

(C) 2021 Codon Publications

OPEN ACCESS (c) (i) (을

RESEARCH ARTICLE

\begin{abstract}
The objective of this study was to evaluate to what extent social media platforms are effective on the marketing performances of food companies. Facebook was the most effective platform in terms of some performance criteria such as time-saving, easy access to customers, customer feedback, brand awareness, marketing costs, order taking frequency, and sales amount. The most effective platforms after Facebook in terms of marketing performance are Instagram and Twitter, respectively. Marketing costs and product sales are factors that affect the attitude of food companies towards social media platforms.
\end{abstract}

Keywords: food, marketing, social media, social media marketing

\section{Introduction}

The research of new marketing methods and the rapid development of technology have improved the marketing techniques. More access to people with the Web has started to move marketing to the digital environment. The convenience of Web marketing for product promotion, services, and to reach potential customers has made companies adopt this method. Companies that promote their marketing activities digitally started to offer product and service promotions at a low cost. Internet marketing is not limited to space and time, makes it more attractive.

Technological changes and constantly changing consumer demands have created new avenues in marketing. Companies use those sites for marketing which has increased usage. For example use of social media (SM) and the awareness of its ease of use attracted companies to these platforms. According to the report published by the SM analysis company 'We Are Social' for 2020, 4.5/ 7.7 billion world population use the Internet, out of which 3.8 billion are active SM users. The active SM users in the world increased by $9.2 \%$ compared with the previous year (We Are Social, 2020). Because of the increase in SM users, companies have started to show their presence on SM platforms (SMPs) to reach users.

Companies that can promote their products and services with minimal marketing expense have started to continue their marketing activities on SM to increase their brand awareness. The use of SM increases the rate of interaction with existing and potential consumers. SM marketing (SMM) is the new media marketing channel that uses SMPs to interact with customers (Yao et al., 2019). SMM makes a significant contribution to companies in terms of customer relationship management by allowing rapid consumer feedback. Companies prefer SMM for fast target audience reach for unique products and for contacting potential customers. Today, SM is also a product research tool for conscious and interested consumers in product research.

SMM has become a preferred marketing channel in many sectors and , has increased marketing food sector products on SM. The global epidemic i.e., the coronavirus (COVID-19); has also increased the tendency of companies to use digital marketing channels for marketing food 
products. However, advertising many nonfood products in the digital environment is easier versus food products owing to seasonal variations, fluctuations in production amount, durability of products, and cultural differences. It is not difficult to predict that the impact of COVID-19 and similar shocks have increased the high consumers' demand in the digital environment. However, without considering the short-term effects of these shocks, it is pivotal to study the effects of SM, one of the most important digital marketing channels, on the marketing performance of companies in the food sector.

This study studied the effect of SMPs on the marketing performance of food companies. This evaluation differs from previous studies in some ways. Previous studies investigating different aspects of this topic have been analyzed within the scope of one or more SMPs where Facebook is predominant (Ainin et al., 2015; Aspasia and Ourania, 2015; Say, 2015; Nyarkoa and Altıntaş, 2015; Saad and Badran, 2016; Francisco, 2016; Yurttadur and Sari, 2017; De Vries et al., 2018; Pantano et al., 2019; Bernal Jurado et al., 2019). In this study, the marketing performance of food companies was analyzed concerning seven SMPs, including Facebook (FB), Twitter (TW), Instagram (IG), YouTube (YT), Google Plus (G+), LinkedIn (LI), and Blogs. In previous studies, the effect of SMM on companies was generally examined within the scope of sales increase (Ainin et al., 2015; Nyarkoa and Altıntaş, 2015; Say, 2015; Canovi and Pucciarelli, 2019) and marketing costs (Ainin et al., 2015; Yurttadur and Sari, 2017; Barišić and Vujnović, 2018; Yao et al., 2019). This study more comprehensively analyzed the effect of SMM on companies with performance criteria such as time-saving, easy access to customers, customer feedback, brand awareness, marketing costs, order taking frequency, and sales amount. Another different aspect of this study from previous studies is that research was conducted on companies operating in different subsectors of the food industry. In previous studies, it is seen that the food sector has been examined in general terms or together with nonfood sectors. This study examined a total of five different subfood sectors.

\section{Materials and Methods}

\section{Data acquisition}

The primary data of this study were obtained from survey interviews with different food subsector companies that actively use SMPs. Five subsectors of food that use SM intensely in the food industry in Turkey were selected that included confectionery (CONF), milk and dairy products (MDP), olive and olive products (OOP), dry food and pulses (DFP), and coffee and tea (CT). Information obtained from SMPs, statistics published by SM analysis companies, and previous research on the subject helped generate the secondary data of this study. A survey was conducted by selecting food brands that actively use SMPs in each subsector. The authors planned to interview 100 companies (20 per sub-sector). Additional surveys were also conducted to eliminate the negativity that may arise from incomplete and erroneous surveys. A total of 101 questionnaires were taken into consideration for data analysis after obtaining the feedback and accuracy levels of the survey. Valid questionnaires received from each subsectors included 19 for CONF, 21 each for MDP and OOP and, 20 each for DFP and CT.

During the selection of food companies in each sector, their FB followers were also considered. Companies with at least 1000 followers were included in the context of the research. For general evaluation of each subsector, companies with different number of followers were selected (between 1000 and 100,000). An online survey was conducted to obtain data from companies using Google Form and was shared with the respective company officials for survey completion.

\section{Statistical analysis}

The data obtained from the surveyed food companies were presented using the five-point Likert scale. The Kruskal-Wallis (KW) test was used to test whether the data means differ in terms of the food subsectors examined. The reason for using this test is that the data do not show normal distribution. Kalaycı (2006) defines the KW test as a nonparametric alternative to a one-way analysis of variance between groups.

\section{Results and Discussion}

\section{General information about the examined food companies}

Table 1 gives the general information about the examined food companies. The legal structure of food companies showed that most of the companies $(56.40 \%)$ operated as limited companies. The rate of food companies operating as sole proprietorships and joint-stock companies was $38.60 \%$ and $5 \%$, respectively.

The activity period of food companies showed that the majority $(88.0 \%)$ have been operating for 10 years or more, $9.90 \%$ of the companies for 4-9 years, and $2 \%$ for 1-3 years. Grouping based on the number of employees revealed that more than half of the companies $(51.50 \%)$ have a workforce of $10-49$ people, $41.60 \%$ of the companies, however, had 50-249 people.

The distribution of domestic and foreign sales of food companies showed that the share of companies with 
Table 1. General characteristics of food companies surveyed. Variables

\begin{tabular}{|c|c|c|}
\hline \multicolumn{3}{|l|}{ Legal structure } \\
\hline Joint stock company & 5 & 5.00 \\
\hline Limited liability company & 57 & 56.40 \\
\hline Sole proprietorship & 39 & 38.60 \\
\hline \multicolumn{3}{|l|}{ Operating period (years) } \\
\hline $1-3$ & 2 & 2.00 \\
\hline $4-9$ & 10 & 9.90 \\
\hline$\geq 10$ & 89 & 88.10 \\
\hline \multicolumn{3}{|l|}{ Number of employees } \\
\hline $1-9$ & 6 & 5.90 \\
\hline $10-49$ & 52 & 51.50 \\
\hline $50-249$ & 42 & 41.60 \\
\hline$\geq 250$ & 1 & 1.00 \\
\hline \multicolumn{3}{|c|}{ Share of domestic sales as a percentage of total sales (\%) } \\
\hline $50-75$ & 8 & 7.92 \\
\hline $76-99$ & 40 & 39.60 \\
\hline 100 & 53 & 52.48 \\
\hline Average domestic sales rate (\%) & & \\
\hline \multicolumn{3}{|c|}{ Share of food products in total sales (\%) } \\
\hline$<50$ & 3 & 2.97 \\
\hline $50-75$ & 6 & 5.94 \\
\hline $76-99$ & 67 & 66.34 \\
\hline 100 & 25 & 24.75 \\
\hline Average share of food sales (\%) & & \\
\hline
\end{tabular}

domestic sales was high. The portion is $92.76 \%$ on average, and $52.48 \%$ of the companies make all their sales domestically. In general, the share of food products in the total turnover of companies was high. The average share of food products in the total turnover of the companies interviewed is $87.38 \%$. The share of food products in the turnover of $66.34 \%$ of the companies varies between $76-99 \%$, and $24.75 \%$ of the examined companies got their entire turnover from the food products sale.

\section{Evaluation of SMPs in terms of marketing performance}

Following the opinions of the examined companies, a comparison of SMPs for marketing performance was conducted. Some performance criteria such as timesaving, easy access to customers, customer feedback, brand awareness, marketing costs, order taking frequency, and sales amount were used to compare SMPs.

Companies need to carry out, follow, and interpret marketing activities in a shorter time. It was observed that companies had started preferring SM applications to perform these activities faster as they wanted to reach more customers in less time.

\section{Effectiveness of SMPs in terms of timesaving}

When the data were analyzed to get an idea about the time-saving platform for companies marketing activities, the FB platform led the list, followed by IG and TW, respectively. In general, companies in different subsector groups find FB, IG, and TW effective for saving time in marketing, and no statistically significant difference was found between the groups. YT and G+ were evaluated as moderately effective, but LI and Blogs are less effective. However, a statistically significant difference of opinion among subsector groups in terms of time savings was noted (Table 2). Companies in the CT and CONF sectors found these four platforms less effective in terms of saving time.

\section{Effectiveness of SMPs for easy customer access}

When the opinions of companies regarding the effectiveness of SMPs for easy access to customers were examined,

Table 2. Evaluation of social media platforms in terms of time-saving.

\begin{tabular}{|c|c|c|c|c|c|c|c|c|c|c|c|c|c|}
\hline \multirow[t]{2}{*}{ SMPs } & \multicolumn{2}{|c|}{ CONF } & \multicolumn{2}{|c|}{ MDP } & \multicolumn{2}{|c|}{ OOP } & \multicolumn{2}{|c|}{ DFP } & \multicolumn{2}{|c|}{ CT } & \multicolumn{2}{|c|}{ Total } & \multirow{2}{*}{$\begin{array}{l}\mathrm{KW} \text { tes } \\
\mathrm{P} \text { value }\end{array}$} \\
\hline & $\bar{x}$ & SD & $\bar{x}$ & SD & $\bar{x}$ & SD & $\bar{x}$ & SD & $\bar{x}$ & SD & $\bar{x}$ & SD & \\
\hline $\mathrm{FB}$ & 4.26 & 1.05 & 4.57 & 0.60 & 4.43 & 0.60 & 4.25 & 0.55 & 4.45 & 0.69 & 4.40 & 0.71 & 0.483 \\
\hline TW & 3.37 & 1.46 & 4.24 & 0.62 & 3.76 & 1.22 & 4.05 & 0.39 & 3.70 & 1.42 & 3.83 & 1.12 & 0.465 \\
\hline IG & 3.37 & 1.57 & 4.19 & 0.68 & 4.00 & 0.84 & 3.70 & 0.86 & 4.05 & 1.05 & 3.87 & 1.06 & 0.298 \\
\hline $\mathrm{YT}$ & 2.16 & 1.07 & 3.71 & 0.90 & 3.24 & 1.04 & 3.60 & 0.88 & 3.00 & 1.12 & 3.16 & 1.13 & $0.000^{*}$ \\
\hline G+ & 2.68 & 1.29 & 3.62 & 0.92 & 3.43 & 0.98 & 3.45 & 1.00 & 2.80 & 1.15 & 3.21 & 1.12 & $0.023^{\star *}$ \\
\hline $\mathrm{LI}$ & 2.21 & 1.08 & 3.24 & 1.09 & 3.14 & 1.01 & 3.35 & 1.09 & 2.45 & 1.32 & 2.89 & 1.19 & $0.005^{*}$ \\
\hline Blogs & 2.11 & 1.10 & 3.33 & 1.06 & 3.24 & 1.00 & 3.35 & 1.09 & 2.70 & 1.26 & 2.96 & 1.18 & $0.003^{*}$ \\
\hline
\end{tabular}

$\bar{x}$ : mean score of the Likert scale by the level of effectiveness of each SMP (1: not at all effective to 5: highly effective); SD: standard deviation.

${ }^{*}$ Statistical significance at $1 \%$.

${ }^{* *}$ Statistical significance at $5 \%$. 
FB with a mean score of 4.52 was determined to be quite effective . Platforms found to be moderately effective in terms of easy access to customers were IG, TW, and YT, respectively (Table 3 ). In general, it was understood that the FB platform was more convenient for food companies to reach their customers. The number of FB users in Turkey is high, causing many customers to focus on this platform. LI (1.87) stands out as the least effective platform concerning easy access to customers as it is primarily business-oriented.

\section{Effectiveness of SMPs concerning customer feedback}

When the opinions of customer feedback on SM were examined, the FB platform was effective in customer feedback with an average score of 4.61 followed by the IG (3.62), and TW was moderately effective (3.29). YT, G+, $\mathrm{LI}$, and Blogs platforms were found to be minimally effective concerning customer feedback (Table 4). The FB, was quite impressive for customer feedback, as it allows users to comment and share, directly message the companies, and provides more notifications from the customers. The IG also offers users the opportunity to comment and send messages to the relevant company. Unlike FB and IG, the sharing of users via text messages is limited on the TW, and the option to send direct messages to the company is often not available. A statistically significant difference was observed between the group evaluations for TW, YT, and Blogs platforms. Compared with the other groups, companies operating in the CONFEC industry did not find TW, YT, and Blogs platforms very effective for customer feedback.

\section{Effectiveness of SMPs for brand awareness}

When the impact of SMPs for increasing brand awareness was analyzed, the FB platform led with an average score of 4.58. Large number of users attribute to its popularity. The other two platforms that were effective in increasing brand awareness were IG (4.22) and TW (4.07), respectively. Other SMPs scored 3.64 (YT ), 3.43 $(\mathrm{G}+$ ), 3.23 ( Blogs), and 3.21 (LI ) concerning their effect on increasing brand awareness (Table 5).

The evaluations made according to the 5-point Likert scale used in the survey study indicated that the

Table 3. The effectiveness of social media platforms in terms of easy access to customers.

\begin{tabular}{|c|c|c|c|c|c|c|c|c|c|c|c|c|c|}
\hline \multirow[t]{2}{*}{ SMPs } & \multicolumn{2}{|c|}{ CONF } & \multicolumn{2}{|c|}{ MDP } & \multicolumn{2}{|c|}{ OOP } & \multicolumn{2}{|c|}{ DFP } & \multicolumn{2}{|c|}{ CT } & \multicolumn{2}{|c|}{ Total } & \multirow{2}{*}{$\begin{array}{l}K W \text { test } \\
P \text { value }\end{array}$} \\
\hline & $\bar{x}$ & SD & $\bar{x}$ & SD & $\bar{x}$ & SD & $\bar{x}$ & $S D$ & $\bar{x}$ & SD & $\bar{x}$ & SD & \\
\hline FB & 4.47 & 1.12 & 4.62 & 0.59 & 4.57 & 0.60 & 4.75 & 0.55 & 4.20 & 0.83 & 4.52 & 0.77 & 0.146 \\
\hline TW & 3.32 & 1.16 & 3.38 & 1.16 & 3.29 & 1.31 & 3.65 & 1.04 & 3.10 & 1.17 & 3.35 & 1.16 & 0.657 \\
\hline IG & 3.63 & 1.12 & 3.81 & 0.98 & 3.90 & 1.00 & 3.90 & 1.17 & 4.00 & 0.97 & 3.85 & 1.03 & 0.829 \\
\hline YT & 2.32 & 1.11 & 2.52 & 1.03 & 2.62 & 1.02 & 2.40 & 1.10 & 2.75 & 1.21 & 2.52 & 1.08 & 0.586 \\
\hline G+ & 2.32 & 1.00 & 2.57 & 0.98 & 2.48 & 0.98 & 2.20 & 0.77 & 2.45 & 1.23 & 2.41 & 0.99 & 0.841 \\
\hline LI & 1.84 & 1.07 & 2.05 & 0.92 & 2.14 & 0.91 & 1.70 & 0.57 & 1.60 & 0.88 & 1.87 & 0.89 & 0.170 \\
\hline Blogs & 1.89 & 0.94 & 2.62 & 1.02 & 2.52 & 0.87 & 2.00 & 0.65 & 2.45 & 1.05 & 2.31 & 0.95 & $0.022^{*}$ \\
\hline
\end{tabular}

$\bar{x}$ : mean score of the Likert scale by the level of effectiveness of each SMP (1: not at all effective to 5 : highly effective); SD: standard deviation. ${ }^{*}$ Statistical significance at $5 \%$.

Table 4. The effectiveness of social media platforms in terms of customer feedback.

\begin{tabular}{|c|c|c|c|c|c|c|c|c|c|c|c|c|c|}
\hline \multirow[t]{2}{*}{ SMPs } & \multicolumn{2}{|c|}{ CONF } & \multicolumn{2}{|c|}{ MDP } & \multicolumn{2}{|c|}{ OOP } & \multicolumn{2}{|c|}{ DFP } & \multicolumn{2}{|c|}{ CT } & \multicolumn{2}{|c|}{ Total } & \multirow{2}{*}{$\begin{array}{l}\mathrm{KW} \text { tes } \\
\mathrm{P} \text { value }\end{array}$} \\
\hline & $\bar{x}$ & SD & $\bar{x}$ & SD & $\bar{x}$ & SD & $\bar{x}$ & $S D$ & $\bar{x}$ & SD & $\bar{x}$ & SD & \\
\hline FB & 4.63 & 0.76 & 4.67 & 0.48 & 4.71 & 0.46 & 4.70 & 0.47 & 4.35 & 0.75 & 4.61 & 0.60 & 0.385 \\
\hline TW & 2.47 & 1.39 & 3.57 & 1.08 & 3.52 & 1.33 & 3.75 & 0.97 & 3.05 & 1.43 & 3.29 & 1.31 & $0.027^{* *}$ \\
\hline IG & 2.95 & 1.58 & 3.90 & 1.00 & 3.71 & 1.27 & 3.75 & 1.07 & 3.75 & 1.12 & 3.62 & 1.24 & 0.301 \\
\hline YT & 1.63 & 1.01 & 2.76 & 1.09 & 2.33 & 1.15 & 2.50 & 1.00 & 2.80 & 1.24 & 2.42 & 1.16 & $0.003^{*}$ \\
\hline G+ & 2.05 & 1.13 & 2.48 & 1.03 & 2.57 & 1.21 & 2.15 & 0.93 & 2.45 & 1.23 & 2.35 & 1.11 & 0.459 \\
\hline $\mathrm{LI}$ & 1.58 & 1.07 & 2.00 & 0.95 & 2.05 & 1.02 & 1.90 & 0.85 & 2.30 & 1.22 & 1.97 & 1.03 & 0.130 \\
\hline Blogs & 1.53 & 1.02 & 2.48 & 0.98 & 2.43 & 1.16 & 2.30 & 0.92 & 2.45 & 1.23 & 2.25 & 1.11 & $0.004^{*}$ \\
\hline
\end{tabular}

$\bar{x}$ : mean score of the Likert scale by the level of effectiveness of each SMP (1: not at all effective to 5: highly effective); SD: standard deviation.

${ }^{*}$ Statistical significance at $1 \%$.

${ }^{*}$ Statistical significance at $5 \%$. 
Table 5. The effect of social media platforms on brand awareness.

\begin{tabular}{|c|c|c|c|c|c|c|c|c|c|c|c|c|c|}
\hline \multirow[t]{2}{*}{ SMPs } & \multicolumn{2}{|c|}{ CONF } & \multicolumn{2}{|c|}{ MDP } & \multicolumn{2}{|c|}{ OOP } & \multicolumn{2}{|c|}{ DFP } & \multicolumn{2}{|c|}{ CT } & \multicolumn{2}{|c|}{ Total } & \multirow{2}{*}{$\begin{array}{l}\mathrm{KW} \text { tes } \\
\mathrm{P} \text { value }\end{array}$} \\
\hline & $\bar{x}$ & SD & $\bar{x}$ & $S D$ & $\bar{x}$ & SD & $\bar{x}$ & SD & $\bar{x}$ & $S D$ & $\bar{x}$ & SD & \\
\hline FB & 4.53 & 0.96 & 4.62 & 0.59 & 4.57 & 0.60 & 4.55 & 0.60 & 4.65 & 0.59 & 4.58 & 0.67 & 0.969 \\
\hline TW & 3.68 & 1.00 & 4.33 & 0.66 & 3.81 & 1.03 & 4.40 & 0.60 & 4.10 & 1.12 & 4.07 & 0.93 & 0.070 \\
\hline IG & 4.00 & 1.11 & 4.48 & 0.68 & 4.14 & 0.79 & 4.00 & 1.17 & 4.45 & 0.69 & 4.22 & 0.91 & 0.353 \\
\hline $\mathrm{YT}$ & 2.89 & 1.24 & 4.05 & 0.67 & 3.57 & 1.08 & 3.55 & 1.05 & 4.10 & 1.02 & 3.64 & 1.09 & $0.004^{*}$ \\
\hline G+ & 2.68 & 1.25 & 3.86 & 0.79 & 3.48 & 1.03 & 3.50 & 1.05 & 3.55 & 1.19 & 3.43 & 1.12 & $0.020^{* *}$ \\
\hline $\mathrm{LI}$ & 2.42 & 1.30 & 3.81 & 0.81 & 3.48 & 0.87 & 3.25 & 1.21 & 3.00 & 1.56 & 3.21 & 1.24 & $0.014^{* *}$ \\
\hline Blogs & 2.26 & 1.28 & 3.86 & 0.79 & 3.29 & 0.96 & 3.25 & 1.21 & 3.40 & 1.47 & 3.23 & 1.25 & $0.003^{*}$ \\
\hline
\end{tabular}

$\bar{x}$ : mean score of the Likert scale by the level of effectiveness of each SMP (1: not at all effective to 5: highly effective); SD: standard deviation.

${ }^{*}$ Statistical significance at $1 \%$.

${ }^{*}$ Statistical significance at $5 \%$.

Table 6. The effect of social media platforms on reducing marketing costs.

\begin{tabular}{|c|c|c|c|c|c|c|c|c|c|c|c|c|c|}
\hline \multirow[t]{2}{*}{ SMPs } & \multicolumn{2}{|c|}{ CONF } & \multicolumn{2}{|c|}{ MDP } & \multicolumn{2}{|c|}{ OOP } & \multicolumn{2}{|c|}{ DFP } & \multicolumn{2}{|c|}{ CT } & \multicolumn{2}{|c|}{ Total } & \multirow{2}{*}{$\begin{array}{l}K W \text { test } \\
P \text { value }\end{array}$} \\
\hline & $\bar{x}$ & SD & $\bar{x}$ & $S D$ & $\bar{x}$ & SD & $\bar{x}$ & SD & $\bar{x}$ & $S D$ & $\overline{\boldsymbol{x}}$ & SD & \\
\hline FB & 4.21 & 1.23 & 4.43 & 0.60 & 4.29 & 0.72 & 4.35 & 0.59 & 4.40 & 0.82 & 4.34 & 0.80 & 0.926 \\
\hline TW & 4.00 & 1.25 & 4.24 & 0.62 & 4.00 & 1.00 & 4.30 & 0.57 & 4.05 & 1.19 & 4.12 & 0.95 & 0.951 \\
\hline IG & 3.89 & 1.33 & 4.24 & 0.62 & 4.24 & 0.70 & 4.05 & 0.76 & 4.25 & 0.97 & 4.14 & 0.89 & 0.823 \\
\hline YT & 3.37 & 1.34 & 3.95 & 0.67 & 3.90 & 0.94 & 3.85 & 0.81 & 4.00 & 0.92 & 3.82 & 0.96 & 0.478 \\
\hline G+ & 3.32 & 1.34 & 3.81 & 0.75 & 3.90 & 0.94 & 3.75 & 0.79 & 3.95 & 0.94 & 3.75 & 0.97 & 0.385 \\
\hline LI & 2.68 & 1.38 & 3.71 & 0.96 & 3.67 & 0.91 & 3.60 & 0.88 & 3.50 & 1.43 & 3.45 & 1.17 & 0.091 \\
\hline Blogs & 2.63 & 1.38 & 3.71 & 0.96 & 3.76 & 0.89 & 3.65 & 0.93 & 3.75 & 1.16 & 3.51 & 1.14 & $0.031^{*}$ \\
\hline
\end{tabular}

$\bar{x}$ : mean score of the Likert scale by the level of effectiveness of each SMP (1: not at all effective to 5 : highly effective); SD: standard deviation. *Statistical significance at $5 \%$.

companies had a positive opinion about the effect of SMPs on brand awareness. A statistically significant difference was found between groups for other SMPs other than FB, IG, and TW. The companies in the CONFEC and MDP sectors were effective in this difference. Companies in the CONFEC industry found SMFs other than FB, IG, and TW had minimal effect of increasing the awareness of their brands. On the other hand, the opinions of the companies in the MDP sector on this issue are more positive versus other subsector groups.

\section{Effectiveness of SMPs in terms of marketing cost reduction}

When the effect of SMPs on reducing marketing costs was analyzed, FB once again led the race with an average of 4.34, followed by IG (4.14) and TW (4.12). Table 6 shows the effectiveness of SMPs on reducing marketing costs. The effect of these platforms in reducing marketing costs was noted as 3 , which is above the neutral value according to the 5-point Likert scale average. The $\mathrm{KW}$ test was conducted to determine whether there is a difference between the evaluations of the company groups regarding the effect of SMPs in reducing marketing costs. A statistically significant difference was found for the Blogs platform. Compared with other food subsectors, companies in the CONFEC industry found the Blogs platform's decreased effect on reducing marketing costs.

According to the results mentioned above, the examined food companies think that SMPs are generally effective in reducing marketing costs. This result is consistent with the findings obtained in previous studies (Ainin et al., 2015; Yurttadur and Sari, 2017; Barišić and Vujnović, 2018; Yao et al., 2019). In particular, the FB platform was evaluated as highly effective in reducing marketing costs, which can be attributed to its free content sharing and easy tracking of user comments.

\section{Effectiveness of SMPs concerning increasing product sales}

When the effect of increasing product sales was examined, FB again led with an average of 4.11, followed by moderate product sales by IG (3.26) and TW (3.15). 
Table 7. The effect of social media platforms in increasing product sales.

\begin{tabular}{|c|c|c|c|c|c|c|c|c|c|c|c|c|c|}
\hline \multirow[t]{2}{*}{ SMPs } & \multicolumn{2}{|c|}{ CONF } & \multicolumn{2}{|c|}{ MDP } & \multicolumn{2}{|c|}{ OOP } & \multicolumn{2}{|c|}{ DFP } & \multicolumn{2}{|c|}{ CT } & \multicolumn{2}{|c|}{ Total } & \multirow{2}{*}{$\begin{array}{l}\mathrm{KW} \text { test } \\
\mathrm{P} \text { value }\end{array}$} \\
\hline & $\bar{x}$ & SD & $\bar{x}$ & SD & $\bar{x}$ & $S D$ & $\bar{x}$ & SD & $\bar{x}$ & SD & $\bar{x}$ & SD & \\
\hline FB & 4.37 & 0.83 & 4.43 & 0.87 & 3.90 & 1.09 & 4.20 & 0.95 & 3.65 & 1.35 & 4.11 & 1.06 & 0.206 \\
\hline TW & 3.00 & 1.20 & 3.57 & 0.87 & 3.00 & 1.38 & 3.40 & 1.10 & 2.75 & 1.59 & 3.15 & 1.26 & 0.336 \\
\hline IG & 3.21 & 1.36 & 3.71 & 0.96 & 3.05 & 1.47 & 3.30 & 1.34 & 3.00 & 1.62 & 3.26 & 1.36 & 0.615 \\
\hline YT & 1.63 & 0.68 & 2.33 & 1.11 & 2.14 & 1.35 & 1.90 & 0.91 & 1.90 & 1.21 & 1.99 & 1.09 & 0.309 \\
\hline G+ & 2.11 & 1.05 & 2.14 & 0.91 & 2.05 & 1.28 & 1.85 & 0.81 & 1.75 & 0.97 & 1.98 & 1.01 & 0.561 \\
\hline LI & 1.68 & 0.67 & 1.95 & 0.86 & 1.76 & 1.00 & 1.70 & 0.73 & 1.45 & 0.69 & 1.71 & 0.80 & 0.348 \\
\hline Blogs & 1.63 & 0.68 & 2.10 & 0.94 & 1.95 & 1.12 & 1.75 & 0.72 & 1.50 & 0.69 & 1.79 & 0.86 & 0.249 \\
\hline
\end{tabular}

$\bar{x}$ : mean score of the Likert scale by the level of effect of each SMP (1: not at all effective to 5: highly effective); SD: standard deviation.

Table 7 reports the impact of YT, G+, Blogs, and LI platforms in enhancing sales.

FB was the most effective platform in the sales increase because of marketing their products via SM, which attributes to the consumers' emphasis on visuality in marketing food products through SM. Ainin et al. (2015) and Say (2015) also revealed that FB effectively increased product sales. Ainin et al. (2015) showed that the use of FB had a positive effect on the sales volume of SMEs in Malaysia. Say (2015) determined that the companies in the convenience food sector in Turkey increase their online sales with campaigns supported by FB. IG was placed second concerning the effect of increasing product sales because of its visual density like FB.

\section{Attitude of food companies towards SMM}

Fifteen statements were presented to companies during the survey study to measure the attitude of companies. Likert scale responses of companies for these statements were tested with reliability analysis. In the analysis, Cronbach's Alpha value, the general reliability coefficient, was determined as 0.873 . Since this value was between $0.80 \leq \alpha<1.00$, the scale was found to be reliable.

The responses of food companies to some statements through SMM are shown in Table 8. The statements to which the companies mostly agree were: providing brand awareness, the convenience of offering products and services to target regions, presenting campaigns and activities at the appropriate time, increasing the competitive power, strengthening the status of the company, reducing marketing expenses, increasing loyal customers, providing tips about the market, and increasing sales.

The statement that the interviewed companies least agreed was about the price. Companies hardly agreed with the view that SMM provides a higher price than traditional marketing. Besides, companies believe that marketing food products on SM are more difficult than other product categories.

In general, there is no statistically significant difference between companies in different food subsectors in terms of their level of agreement with some statements related to SMM. There is a statistical difference of opinion among companies for statements that "social media enables customers to make better decisions" and "social media is preferred over other marketing channels." However, the degree to which companies agree with both statements is high.

Table 9 shows the correlation analysis results of the relationship between the general attitude of companies towards SMM. These results revealed that the attitude of companies towards SM is not in a statistically significant relationship with the size of the companies, operating period of the companies, and the SMM experience of the companies.

The correlation analysis was used to determine the attitude change toward SM according to the company size. However, there was no significant relationship found between company size and attitude toward SM. This aspect was not examined in previous studies. However, some studies investigated the relationship between company size and SM use. Aspasia and Ourania's (2014) study on the Greek food sector found a positive relationship between company size and the adoption of SM tools. According to the authors, this is because large firms allocate more staff and budget to SM. Braojos-Gomez et al. (2015) and Pantano et al. (2019) state that small companies with low financial resources must improve their SM skills to gain a competitive advantage in SM. Tarsakoo and Charoensukmongkol (2019) argue that both small and large companies use SM to add value to their business activities. But many difficulties that limit the capabilities of small companies in terms of effective SMM.

On the other hand, the increasing effect of SM on reducing marketing costs positively increases the attitude of 
Table 8. Level of agreement of food companies with some statements on social media marketing.

\begin{tabular}{|c|c|c|c|c|c|c|c|c|c|c|c|c|c|}
\hline \multirow[t]{2}{*}{ Statements } & \multicolumn{2}{|c|}{ CONF } & \multicolumn{2}{|c|}{ MDP } & \multicolumn{2}{|c|}{ OOP } & \multicolumn{2}{|c|}{ DFP } & \multicolumn{2}{|c|}{ CT } & \multicolumn{2}{|c|}{ Total } & \multirow{2}{*}{$\begin{array}{l}\mathrm{KW} \text { test } \\
\mathrm{P} \text { value }\end{array}$} \\
\hline & $\bar{x}$ & SD & $\bar{x}$ & SD & $\bar{x}$ & SD & $\bar{x}$ & SD & $\bar{x}$ & SD & $\bar{x}$ & SD & \\
\hline $\begin{array}{l}\text { SM increases brand } \\
\text { awareness }\end{array}$ & 4.16 & 0.90 & 4.52 & 0.51 & 4.43 & 0.68 & 4.30 & 0.66 & 4.40 & 0.60 & 4.37 & 0.67 & 0.645 \\
\hline $\begin{array}{l}\text { It is easier to reach the } \\
\text { target audience with SM }\end{array}$ & 3.89 & 0.99 & 4.43 & 0.60 & 4.43 & 0.60 & 4.20 & 0.62 & 4.30 & 0.86 & 4.26 & 0.76 & 0.236 \\
\hline $\begin{array}{l}\text { SM is effective for } \\
\text { campaigns }\end{array}$ & 3.87 & 1.13 & 4.14 & 0.48 & 4.38 & 0.59 & 4.55 & 0.60 & 4.30 & 0.66 & 4.25 & 0.74 & 0.100 \\
\hline $\begin{array}{l}\text { SM gives a competitive } \\
\text { edge }\end{array}$ & 3.81 & 0.93 & 4.27 & 0.76 & 4.36 & 0.72 & 4.31 & 0.62 & 4.38 & 0.57 & 4.23 & 0.74 & 0.161 \\
\hline $\begin{array}{l}\text { SM strengthens the } \\
\text { status of the company }\end{array}$ & 3.84 & 0.83 & 4.43 & 0.51 & 4.43 & 0.60 & 4.15 & 0.49 & 4.10 & 0.79 & 4.20 & 0.68 & 0.059 \\
\hline $\begin{array}{l}\text { SM reduces marketing } \\
\text { expenses }\end{array}$ & 3.74 & 0.99 & 4.38 & 0.50 & 4.19 & 0.75 & 4.15 & 0.67 & 4.40 & 0.60 & 4.18 & 0.74 & 0.120 \\
\hline $\begin{array}{l}\text { SM increases loyal } \\
\text { customers }\end{array}$ & 3.69 & 1.06 & 4.19 & 0.60 & 4.38 & 0.67 & 4.05 & 0.51 & 4.20 & 0.77 & 4.11 & 0.76 & 0.163 \\
\hline $\begin{array}{l}\text { SM provides market- } \\
\text { related tips }\end{array}$ & 4.06 & 0.91 & 4.14 & 0.57 & 4.19 & 0.60 & 3.90 & 0.55 & 4.20 & 0.62 & 4.10 & 0.66 & 0.400 \\
\hline SM increases sales & 3.95 & 0.78 & 4.00 & 0.77 & 3.81 & 1.08 & 3.75 & 0.85 & 4.05 & 1.05 & 3.91 & 0.91 & 0.704 \\
\hline $\begin{array}{l}\text { SM enables customers } \\
\text { to make better decisions }\end{array}$ & 3.57 & 0.76 & 3.95 & 0.59 & 4.05 & 0.67 & 3.64 & 0.74 & 4.20 & 0.77 & 3.89 & 0.73 & $0.023^{* *}$ \\
\hline Selling on SM is easy & 3.84 & 0.90 & 3.73 & 0.62 & 3.98 & 0.71 & 3.68 & 0.56 & 4.19 & 0.70 & 3.88 & 0.71 & 0.078 \\
\hline $\begin{array}{l}\text { I prefer SM to other } \\
\text { marketing channels }\end{array}$ & 3.28 & 1.14 & 3.71 & 0.64 & 3.86 & 0.57 & 3.38 & 0.49 & 4.05 & 0.69 & 3.66 & 0.77 & $0.008^{*}$ \\
\hline $\begin{array}{l}\text { SM offers special } \\
\text { products to customers }\end{array}$ & 3.03 & 1.00 & 3.11 & 0.86 & 3.05 & 0.90 & 3.12 & 0.21 & 3.18 & 1.31 & 3.10 & 0.91 & 0.673 \\
\hline $\begin{array}{l}\mathrm{SM} \text { is a good option } \\
\text { for marketing food } \\
\text { products. }\end{array}$ & 2.90 & 1.07 & 2.57 & 1.00 & 2.52 & 0.95 & 2.52 & 0.73 & 2.58 & 1.40 & 2.62 & 1.04 & 0.365 \\
\hline $\begin{array}{l}\text { Sellers on SM get } \\
\text { higher prices }\end{array}$ & 2.01 & 1.23 & 1.84 & 1.13 & 1.51 & 0.71 & 1.73 & 0.82 & 2.20 & 1.34 & 1.85 & 1.08 & 0.526 \\
\hline
\end{tabular}

$\bar{x}$ : mean score of likert scale by the level of agreement with statements (1: not at all effective to5: highly effective); SD: standard deviation.

${ }^{*}$ Statistical significance at $1 \%$.

${ }^{*}$ Statistical significance at $5 \%$.

Table 9. Correlation analysis results between the attitude of companies towards social media.

\begin{tabular}{|c|c|c|c|c|c|c|c|}
\hline & & $\begin{array}{l}\text { Attitude of } \\
\text { companies } \\
\text { towards SM }\end{array}$ & $\begin{array}{l}\text { Size of the } \\
\text { companies }\end{array}$ & $\begin{array}{l}\text { Operating } \\
\text { period of the } \\
\text { companies }\end{array}$ & $\begin{array}{c}\text { SMM } \\
\text { experience of } \\
\text { the companies }\end{array}$ & $\begin{array}{l}\text { Effect of SM on } \\
\text { reducing } \\
\text { marketing costs }\end{array}$ & $\begin{array}{l}\text { Effect of SM } \\
\text { on increasing } \\
\text { product sales }\end{array}$ \\
\hline \multirow{2}{*}{$\begin{array}{l}\text { Attitude of } \\
\text { companies } \\
\text { towards SM }\end{array}$} & Pearson Correlation & 1.000 & 0.114 & -0.182 & -0.030 & $0.216^{* *}$ & $0.317^{*}$ \\
\hline & Sig. (2-tailed) & - & 0.255 & 0.069 & 0.763 & 0.030 & 0.001 \\
\hline
\end{tabular}

companies toward SMM $(r=0.216 ; \mathrm{P}=0.030)$. Analysis findings also revealed a statistically significant and positive relationship $(\mathrm{r}=0.317, \mathrm{p}=0.001)$ between the increasing effect of SM on product sales and attitude toward SM. Although the relationship between them is not strong, according to the size of the correlation coefficients, the effect of SM, both to reduce marketing costs and increase product sales positively affects the attitudes of companies toward SM. However, the highest degree of relation with the attitude of companies towards SM is the increasing effect of SM on product sales. 


\section{Conclusion}

This study examined the effectiveness of SMPs on the marketing performance of food companies. According to the outcomes, FB is the most effective platform for performance criteria such as time-saving, easy access to customers, customer feedback, brand awareness, marketing costs, order taking frequency, and sales amount. The most effective platforms after FB in terms of marketing performance are IG and TW, respectively. LI, Blogs, and $\mathrm{G}+$ are the platforms with the least performance.

The marketing performance of food companies varies according to SMPs. The use of all SM platforms for marketing purposes will waste the time of companies. Hence, a company should first determine which SMP their current and target customers use more. In the next stage, these companies should conduct their marketing activities over the SMP chosen. A food company that is engaged in marketing activities on a platform where there are no current and target customers will not reach the SM usage purpose. Since the content offered by the food company cannot reach current and target customers, SMM will not have an impact on the product sales of the company. Besides, companies need to follow the SM activities of their competitor companies while continuing their marketing activities on SM. Food companies to examine the content on SM provided by competitors that produce similar products and their feedback.

Enhancing the company's knowledge on the use of SM and SMM will aid in increasing the marketing effectiveness of food companies on SM. In general, the food companies make intensive marketing initiatives on SM. However, they do show their competence in using SMPs. It has been observed that some companies have incorrect/ no or nonsuitable information entered in their SM accounts. Food companies should start operating on SM after doing a good research on using the functional features of SMPs as every SMP has options specific to the platforms it offers. Since marketing strategies will change according to platforms, preliminary research is required on this subject. In addition, visually intensive shares for food products should be presented to the consumer. Hence, food companies need to pay attention to the quality and remarkable features of the content offered on SM. Rapid and positive feedback of food companies on SM will be a supportive effort to achieve the SMM goal.

\section{Acknowledgments}

The authors thank the food companies for their valuable contributions in study data collection.

\section{Conflict of Interest}

No potential conflict of interest was reported by the authors.

\section{References}

Ainin S., Parveen F., Moghavvemi S., Jaafar N.I. and Mohd Shuib, N.L. 2015. Factors influencing the use of social media by SMEs and its performance outcomes. Ind. Manag. Data Syst. 115(3): 570-588. https://doi.org/10.1108/IMDS-07-2014-0205

Aspasia V. and Ourania N. 2014. Social media adoption and managers' perceptions. Int. J. Strategic Innovative Mark. 1: 61-73. https://doi.org/10.15556/IJSIM.01.02.001

Aspasia V. and Ourania N. 2015. Greek food manufacturing firms' social media efforts: evidence from FB. Procedia Soc. Behav. Sci. 175: 308-313. https://doi.org/10.1016/j.sbspro.2015.01.1205

Barišić A.F. and Vujnović K. 2018. Attitudes of entrepreneurs towards social media as a marketing tool. J. Entrep. Educ. 8: 139-154.

Bernal Jurado E., Fernández Uclés D., Mozas Moral A. and Jesús Medina Viruel M. 2019. Agri-food companies in the social media: a comparison of organic and non-organic firms. Econ. Res. Ekon. Istraz. 32(1): 321-334. https://doi.org/10.1080/1331 677X.2018.1547203

Braojos-Gomez J., Benitez-Amado J. and Llorens-Montes J. 2015. How do small firms learn to develop a social media competence? Int. J. Inf. Manag. 35(4): 443-458. https://doi.org/10.1016/j. ijinfomgt.2015.04.003

Canovi M. and Pucciarelli F. 2019. Social media marketing in wine tourism: winery owners' perceptions. J. Travel Tour. Mark. 36(6): 653-664. https://doi.org/10.1080/10548408.2019.1624241

De Vries H.P., Veer E. and De Vries K.V. 2018. An examination of SME social media use in the food industry. Small Enterp. Res. 25(3): 227-238. https://doi.org/10.1080/13215906.2018.1521741

Francisco C.B.H. 2016. Social media marketing in fast food chains: benefits' role in increasing brand community participation and its influence on brand trust and brand commitment. MSc Thesis, College of Business, Economics, Accountancy and Management, De La Salle Lipa, Philippines.

Kalaycı Ş. 2006. Multivariate statistics techniques using SPSS. 2nd ed. Asil Publishing, Ankara.

Nyarkoa M. and Altıntaş T. 2015. Social media marketing and a case study on food manufacturing in Ghana. ABMYO Dergisi. 37: 111-125. https://dergipark.org.tr/tr/pub/abmyoder/issue/ 46669/585177

Pantano E., Priporas C.V. and Migliano G. 2019. Reshaping traditional marketing mix to include social media participation: evidence from Italian firms. Eur. Bus. Rev. 31(2):162-178. https:// doi.org/10.1108/EBR-08-2017-0152

Saad H.E. and Badran N.A. 2016. How successful is fast food social media marketing? International vs. local chains. IJHTH. 10(2/2): 302-320.

Say S. 2015. Using social media as a marketing tool: Facebook case study in the food industry. MSc Thesis, Kocaeli University, 
Institute of Social Sciences, Production Management and Marketing Department, Kocaeli, Turkey.

Tarsakoo P. and Charoensukmongkol P. 2019. Dimensions of social media marketing capabilities and their contribution to business performance of firms in Thailand. J. Asia Bus. Stud 14(4):441461. https://doi.org/10.1108/JABS-07-2018-0204

We Are Social. 2020. Digital 2020 Global Overview Report. Retrieved from https://wearesocial.com/digital-2020 (Accessed August 30, 2020)
Yao B., Shanoyan A., Peterson H.H., Boyer C. and Baker L. 2019. The use of new-media marketing in the green industry: analysis of social media use and impact on sales. Agribusiness. 35: 281297. https://doi.org/10.1002/agr.21581

Yurttadur M. and Sari D. 2017. A study on financial aspect of traditional food shopping via social media. PAP. 4(1):105-113. https://doi.org/10.17261/Pressacademia.2017.524 